\title{
Crime passional e a privilegiadora da violenta emoção
}

\section{Passional crime and privilegiadora of violent emotion}

Crimen pasional y privilegiadora de emoción violenta João Antonio Dias Morais ${ }^{1}$

${ }^{1}$ Bacharel em Direito. Pós-graduando em Direito Processual Civil. Aluno especial do mestrado de Políticas Sociais e Cidadania pela UCSAL. Servidor do Ministério Público de Sergipe. Ministério Público de Sergipe. E-mail: jadm07@hotmail.com 
Resumo: O presente trabalho abordará os aspectos que envolvem a legítima defesa da honra no crime de homicídio, notadamente como uma causa privilegiadora do crime em análise. Pretende-se, a partir deste estudo, abordar a problemática que envolve a legítima defesa da honra como causa excludente de ilicitude nos crimes passionais, bem como fazer uma breve análise das teses de defesa destes. O objetivo primordial é possibilitar uma visão global acerca desse tipo de crime, sua posição no ordenamento jurídico, no passado e na sociedade atual, bem como identificar quais são os fundamentos utilizados no julgamento do criminoso passional, analisando a legítima defesa da honra como causa excludente de ilicitude.

Palavras-chave: crime passional; honra; legítima defesa.

Abstract: This paper will discuss the aspects involving the legitimate defense of honor in the crime of murder, especially as a privilegiadora because of the crime in question. It is intended, from this study, to address the problem involving the legitimate defense of honor as a cause legal excuse the crimes of passion and make a brief analysis of the defense of these theses. The primary objective is to enable a global vision of this type of crime, its position in the legal system in the past and in today's society, and to identify which are the foundations used in the trial of passionate criminal, analyzing legitimate defense of honor as a cause exclusionary of unlawfulness.

Key words: crime of passion; honor; self defense.

Resumen: Este artículo discutirá los aspectos relacionados con la legítima defensa del honor en el delito de homicidio, en especial como privilegiadora debido al delito de que se trate. Se pretende, de este estudio, para hacer frente al problema que implica la legítima defensa del honor como una excusa legal la causa de los crímenes de pasión y hacer un breve análisis de la defensa de estas tesis. El objetivo principal es permitir una visión global de este tipo de delito, su posición en el sistema legal en el pasado y en la sociedad actual, e identificar cuáles son las bases utilizadas en el juicio del criminal pasión, el análisis de legítima defensa del honor como causa de exclusión de ilegalidad.

Palabras clave: crimen pasional; honor; la autodefensa. 


\section{INTRODUÇÃO}

A conduta delituosa fatidicamente sempre esteve enraizada junto à sociedade, sendo o homicídio um dos crimes mais comuns praticados pelo homem. O homicídio se configura quando há a morte de uma pessoa praticada por outra pessoa, utilizando esta de qualquer meio capaz da concretização desse ato. O sujeito ativo pode ser qualquer indivíduo, pois se trata de crime comum, de modo que a lei não exige nenhum requisito especial para assim o considerar.

Estudiosos do tema, como Nucci, Eluf, Bernardes, Capez, dentre outros, convergem no conceito de homicídio passional como sendo uma modalidade de delito que se materializa em função de uma paixão desenfreada, munida de sentimentos de posse, ciúmes, amor e ódio, desencadeada pela não aceitação do término de um relacionamento amoroso ou pela traição, tendo como raiz fatores intrínsecos e extrínsecos.

Neste estudo, tentar-se-á, por meio de uma pesquisa exploratória descritiva, analisar os diversos fatores que envolvem os crimes passionais e mostrar que diversas são as formas de interpretação sobre conduta do criminoso que, por vezes, é absolvido ou ainda condenado. $\mathrm{O}$ presente estudo pretende analisar o que envolve o crime passional, os sentimentos que estão permeados e o atual posicionamento da sociedade (órgão julgador) em relação às teses de defesa levantadas para tentar justificar a absolvição e/ou eventual condenação do autor do crime.

Far-se-á neste trabalho uma análise sobre tudo aquilo que envolve esses crimes, ou seja, paixão, amor, ciúme, legítima defesa da honra e a tese da privilegiadora de violenta emoção, e como estes institutos são recepcionados pela sociedade, de acordo com seus valores morais e sociais, demonstrando o atual entendimento do ordenamento jurídico e do meio social acerca da questão da legítima defesa da honra. 


\section{HOMICÍDIO PASSIONAL}

De início, cabe ressaltar que a violenta emoção não é sinônimo de passionalidade. A palavra paixão é derivada do latim "passio" e expressa sofrimento, amor ardente, excessivo; afeto violento; entusiasmo; vício dominante; alucinação; sofrimento intenso e prolongado (MICHAELIS, 1998).

Nessa seara, infere-se que a passionalidade remete a algo que vai além da razão e lucidez, impelindo o agente a praticar o delito que, na maioria das vezes, foi cuidadosamente premeditado.

O Código Penal Brasileiro tipifica, em seu artigo 121 caput, o crime de homicídio. Não existe na legislação uma definição do que é homicídio passional, cabendo à doutrina a sua conceituação. Vale a pena mencionar que, em legislações anteriores, havia a previsão do crime de adultério, no qual o cônjuge traído tinha amparo moral e jurídico caso viesse a ceifar a vida do cônjuge traidor, de modo que sua honra fosse lavada.

É sabido que o homicídio passional é um crime de grande notoriedade, haja vista reunir nele sentimentos bastante intrínsecos, que misturam amor e paixão. Ele é descrito como um crime que é cometido por paixão, por uma forte emoção irresistível que tem como final o resultado morte, ressaltando que é devida a uma relação amorosa entre a vítima e o autor.

Certos homicídios são chamados de "passionais". O termo deriva de "paixão"; portanto, crime cometido por paixão. Todo crime é, de certa forma, passional, por resultar de uma paixão no sentido amplo do termo. Em linguagem jurídica, porém, convencionou-se chamar de "passional" apenas os crimes cometidos em razão de relacionamento sexual ou amoroso. (ELUF, 2007, p. 156).

Segundo Bernardes (2007), o crime passional é derivado de qualquer fato que produza na pessoa emoção intensa e prolongada, ou simplesmente paixão, não aquela de que descrevem os poetas, a 
paixão pura, mas paixão embebida de ciúmes, de posse, embebida pela incapacidade de aceitação do fim de um relacionamento amoroso, que tanto pode vir do amor ou do ódio, da ira e da própria mágoa.

O crime passional não possui enquadramento no Código Penal, mas em seu artigo 28 está evidenciado, quando dispõe que: "Art. 28- Não excluem a imputabilidade penal: I- a emoção ou a paixão".

No entendimento de Capez (2007), a emoção é entendida como algo súbito, arrebatador, movido por sentimentos que envolvem e toma a pessoa tal qual um vendaval, tanto quanto é efêmero, passageiro, esvaindo-se com a mesma rapidez. Em contraponto, a paixão é um sentimento lento, que se vai cristalizando paulatinamente na alma humana até alojar-se de forma definitiva.

A emoção e a paixão são dois sentimentos que são tratados em nosso Código Penal Brasileiro (artigo 28, inciso I, do CP), e não excluem a imputabilidade penal, impedindo o agente alegar que não tinha capacidade intelectiva quando realizou a conduta delituosa. Acerca de tal afirmação, Bitencourt (2009, p. 92) assevera:

Em nosso direito positivo a emoção e a paixão não apresentam maiores problemas, embora possam reduzir, inegavelmente, $a$ vis electiva entre o certo e o errado. Esses estados emocionais não eliminam a censurabilidade da conduta (art. 28, I, do CP); poderão, apenas, diminuí-las, com a correspondente redução de pena, desde que satisfeitos determinados requisitos legais.

Muito embora o homicídio passional tenha como característica o cometimento por sentimentos ligados ao amor è̀ paixão, vale lembrar que pode haver um erro de interpretação em que outro homicídio pode ser cometido e intitulado como passional, escondendo o seu principal motivo. Corroborando com esse raciocínio, elucida o autor:

É sobremodo importante assinalar que juridicamente, não é qualquer delito no âmbito amoroso que se caracteriza como passional, pois, por exemplo, se o homicídio é em função de 
que o homem espancava a mulher, ou visando um seguro de vida, ou mesmo que após a morte do cônjuge desejava ficar maritalmente com a amante, não há que se enquadrar no objeto do estudo em tela. (FERLIN, 2014, p.1).

Desta feita, não há de se negar que erroneamente as palavras amor e paixão foram empregadas de maneira equivocada para justificar o cometimento de tamanha torpeza, uma vez que o crime passional se manifesta por uma exaltação de sentimentos que ora se confundem, em consequência de um desmedido amor a outra pessoa. Assim, esse tipo de crime remete à ideia de que o agente produtor de tal conduta perde o controle sobre suas emoções, a ponto de não entender que sua conduta, vinda do amor como do ódio, traz consequências irreparáveis.

Vale ressaltar que, na maioria dos casos, a mulher comete esse tipo de crime no afã da emoção, por impulso, já o homem age de forma premeditada. Pondera Eluf que o Código Penal menciona que o motivo do homicídio pode qualificar o crime. Dessa forma, dependendo da ação delituosa, o sujeito será punido com maior ou menor rigor. Sabendo que diversos são os motivos que levam um sujeito a ceifar a vida de outro, pode-se inferir que dentre as razões mais reprováveis para tirar a vida de alguém, estão o motivo torpe e o fútil.

Em se tratando de homicídio passional, não caberia qualificá-lo como um motivo fútil, pois aqui o sujeito está tomado por um misto de sentimentos, desejando tão somente a vingança. Sendo assim, se enquadraria aqui o motivo torpe.

\section{A LEGÍTIMA DEFESA DA HONRA}

Numa época pretérita, a lei brasileira admitia que um homem ceifasse a vida da mulher e/ou do amante dela em caso de adultério. Se o contrário fosse, isto não teria validade. Em 1830, no primeiro Código Penal do Brasil, essa regra foi eliminada. Posteriormente, em 
1890, o homicídio praticado sob intensa emoção causada por perturbação dos sentidos, deixou de ser considerado crime. À época, alguns sentimentos experimentados pela pessoa traída eram capazes de provocar uma insanidade momentânea, justificando assim seu cometimento e isentando o criminoso da pena.

O atual Código Penal, promulgado em 1940, suprimiu a excludente de ilicitude no que concerne à perturbação dos sentidos e da inteligência, ao conferir nova roupagem, com a denominação de homicídio privilegiado.

Sob a égide da Constituição Federal de 1988, em seu art. 5ㅇ, X, a honra é asseverada como cláusula pétrea, adornada de proteção de direito e garantia fundamental como bem preconiza: " $X$ - são invioláveis a intimidade, a vida privada, a honra e a imagem das pessoas, assegurando o direito a indenização pelo dano material e moral decorrente da sua violação".

No que alude ao instituto da legítima defesa, este tem previsão legal no nosso atual Código Penal Brasileiro, em seu artigo 25, que dispõe: "Entende-se em legítima defesa quem, usando moderadamente dos meios necessários, repele injusta agressão, atual ou iminente, a direito seu ou de outrem".

Trata-se de uma excludente de ilicitude, que leva o indivíduo a repelir a agressão a um bem tutelado, devendo estar evidenciado que esta seja atual ou iminente, de modo sempre a prezar pela moderação, para que o bem jurídico seja preservado, dentro dos limites estabelecidos por lei.

Conforme menciona Celso Delmanto (2008), quando uma pessoa age em legítima defesa, protegendo direito seu ou alheio, em caso de excepcional urgência, em face de uma agressão injusta, atual ou iminente, não tem o cidadão, naquele instante, como recorrer ao Estado para assegurar a proteção do bem jurídico que está sendo ameaçado pelo agressor, como a sua vida ou a de terceiro [...]. Ou ele, 
com moderação, contra-ataca, ou o injusto agressor irá ter sucesso em sua criminosa empreitada. Trata-se, assim, de uma atuação necessária e ínsita a um dos mais elementares instintos humanos: o da preservação. Na legítima defesa deve ser analisada a proporcionalidade entre a ofensa e a repulsa, conforme assevera Capez (2007, p. 288):

Em princípio, todos os direitos são suscetíveis de legítima defesa, tais como a vida, a liberdade, a integridade física, o patrimônio, a honra etc., bastando que esteja tutelado pela ordem jurídica. Dessa forma, o que se discute não é a possibilidade da legítima defesa da honra e sim a proporcionalidade entre ofensa e a intensidade da repulsa. Nessa medida, não poderá, por exemplo, o ofendido, em defesa da honra, matar o agressor, ante a manifesta ausência de moderação. No caso de adultério, nada justifica a supressão da vida do cônjuge adúltero, não apenas pela falta de moderação, mas também devido ao fato de que a honra é um atributo de ordem personalíssima, não podendo ser considerada ultrajada por um ato imputável a terceiro, mesmo que este seja a esposa ou o marido do adúltero.

Seguindo o mesmo raciocínio, assim preleciona Toigo:

A legítima defesa consiste no uso dos meios necessários e se o ofendido julgava no momento de sua exaltação emocional e psicológica que, aquele era o meio necessário para a repulsa da ofensa e não era capaz de discernir se aquela repulsa era necessária ou se a melhor saída seria a separação litigiosa ou consensual, não há que se desclassificar a legitima defesa e puni-lo por homicídio qualificado, ou na melhor das hipóteses no homicídio privilegiado. O que deve ser analisado é núcleo do tipo penal, ou seja, repulsa a injusta agressão a honra, que caracteriza a legítima defesa. (TOIGO, 2010, p. 16, apud BERALDO JUNIOR, 2004, p. 1).

O artigo 23, parágrafo único do Código Penal Brasileiro, salienta que, se o agente praticar a legítima defesa com excesso, responderá pelo excesso doloso ou culposo. Dessa forma, existe aqui uma limitação da excludente de ilicitude, pois deverá o agente moderar seus 
atos para que seja reconhecida a referida tese. Corroborando com esse raciocínio, esclarece Bitencourt (2009, p. 71):

Em qualquer das causas de justificação, quando o agente, dolosa ou culposamente, exceder-se nos limites da norma permissiva, responderá pelo excesso. O excesso pode ocorrer em qualquer das modalidades de excludente. Ademais, esse excesso pode decorrer de dolo, de culpa ou simplesmente de caso fortuito, hipótese em que não se poderá falar de responsabilidade penal.

Desta feita, a legítima defesa é uma modalidade de excludente de ilicitude, prevista no Código Penal Brasileiro, cabendo à doutrina identificar seus tipos e formas cabíveis de aplicação. No raciocínio de Maggiore, citada na obra do doutrinador Guilherme de Souza Nucci (2012, p. 258), é esclarecido que:

O conceito de justificação não é particular e exclusivo do direito penal, pertencendo ao direito em geral, tanto público como privado, pois é faculdade do ordenamento jurídico decidir se uma relação determinada é contrária ao direito ou está de acordo com ele. A excludente de antijuricidade torna lícito o que é ilícito.

Ainda na mesma linha do raciocínio de Guilherme de Souza Nucci (2012):

O Direito também tem, inegavelmente, a missão de educar a sociedade, incentivando, por meio da edição de normas, pensamentos e posturas mais nobres - e outra não é a explicação para combatermos a tortura, as penas degradantes e cruéis e caminhos menos elevados para a dignificação da vida em sociedade. Dessa forma, ainda que o brasileiro médio possua a concepção de que a honra se lava com sangue - e tal postura é exercitada não somente no contexto do flagrante adultério torna-se indispensável que o legislador, sensível à importância do valor da vida, jamais deixe de se voltar ao direito ideal e não somente ao pensamento coletivo real, por vezes envolto de 
banalidade, agressividade, egoísmo e mesquinharias de toda ordem. Não se descura, em aspecto relevante para a honra objetiva do cônjuge traído, da possibilidade de haver uma reação momentânea, quando se depara com uma ofensa à sua reputação, mormente no delicado contexto do adultério. Toda a energia e paixão geradas em seu espírito não podem motivar, com o beneplácito da lei, um julgamento sumário, feito em regime puramente emocional, sem qualquer chance de defesa, ceifando a vida do cônjuge traidor e mesmo do amante. [...] Desnecessária, certamente, a solução fatal, impondo pena de morte a quem comete o deslize. Repita-se que o mais condizente, nessa situação, é aceitar uma reação moderada, expulsando de casa o ofensor, destruindo algum bem do traidor ou mesmo do amante, enfim, demonstrando seu inconformismo, mas sempre com o controle que se espera do ser humano preparado a viver em sociedade. A honra sexual não pode tornar-se o grande apanágio a justificar a inversão de valores e a submissão da vida à reputação, mesmo porque inúmeros mecanismos existem para reparar a situação. Atualmente, tem-se até mesmo admitido a indenização por dano moral a quem se julga traído pelo cônjuge. A evolução do pensamento humano é esperada e deve ser fomentada pelo direito, sem jamais se esquecer o legislador da realidade. O homicídio, caso aceito pelo direito como solução legítima para reparar a honra ferida, é o atestado nítido da involução, de regressão aos costumes mais bárbaros, passo indesejável quando se pretende construir, cada vez mais, uma sociedade amparada pelo respeito aos valores e direitos fundamentais do ser humano.

Ensina Bitencourt acerca do instituto da legítima defesa, ao afirmar que este é um dos institutos jurídicos mais bem elaborados através dos tempos, representa uma forma abreviada de realização da justiça penal e da sua sumária execução. Na definição do Código Penal, "entende-se em legítima defesa quem, usando moderadamente dos meios necessários, repele injusta agressão, atual ou eminente, a direito seu ou de outrem" (art. 25) (BITENCOURT, 2009, p. 81). Dessa 
forma, possível é um sujeito se valer dos meios necessários para repelir uma injusta agressão, lembrando que deverá sempre prezar pela sua moderação.

O instituto da legítima defesa da honra fundamentou diversas decisões judiciais para inocentar réus autores do crime de homicídio contra suas mulheres. Santana menciona que:

O Código Penal, que durou de 1890 a 1940, no artigo 27, não considerava ilicitude os atos cometidos por pessoas que "se acharem em estado de completa privação de sentidos e de inteligência no ato de cometer o crime". Tal formulação orientava juízes à falsa e famigerada tese da legítima defesa da honra, absolvendo réus que praticaram crimes contra as suas companheiras. (SANTANA, 2015).

Capez ensina que, em princípio, todos os direitos são suscetíveis de legítima defesa, tais como a vida, a liberdade, a integridade física, o patrimônio, a honra etc., bastando que esteja tutelado pela ordem jurídica. É preciso tão somente que esteja presente a proporcionalidade entre a ofensa e a intensidade da repulsa. Sendo assim, não poderá, por exemplo, o ofendido, em defesa da honra, matar o agressor, ante a manifesta ausência de moderação. No caso de adultério, nada justifica a supressão da vida do cônjuge adúltero, não apenas pela falta de moderação, mas também devido ao fato de que a honra é um atributo de ordem personalíssima, não podendo ser considerada ultrajada por um ato imputável a terceiro, mesmo que este seja a esposa ou o marido do adúltero (CAPEZ, 2007, p. 288).

É sabido que diversos doutrinadores defendem a legítima defesa da honra, ressaltando que esta tem aplicabilidade até nos dias atuais. De acordo com Beraldo Junior (2004), a ideia de legítima defesa da honra tem validade, uma vez que a honra deve ser reconhecida como direito, conforme a Constituição Federal de 1988, em seu art. 50, inciso X. Desta feita, segundo Beraldo Junior (2004, p. 1): 


\begin{abstract}
A legítima defesa consiste no uso dos meios necessários e se o ofendido julgava no momento de sua exaltação emocional e psicológica que, aquele era o meio necessário para a repulsa da ofensa e não era capaz de discernir se aquela repulsa era necessária ou se a melhor saída seria a separação litigiosa ou consensual, não há que se desclassificar a legitima defesa e puni-lo por homicídio qualificado, ou na melhor das hipóteses no homicídio privilegiado. O que deve ser analisado é núcleo do tipo penal, ou seja, repulsa a injusta agressão a honra, que caracteriza legitima defesa.
\end{abstract}

Existe indiscutivelmente grande discussão sobre a aplicação da legítima defesa da honra, abrindo a possibilidade de ser utilizada como causa de privilégio prevista no art. 121, §1으 do CP, caso não exclua a ilicitude do fato.

A validade da legítima defesa da honra se fundamentava na tese de que o agente não possuía o discernimento adequado, a alteração emocional e psicológica para tal repulsa de desonra, o que motiva a prática do crime. Essa tese foi muito utilizada no passado, mas não foi totalmente sanada dos nossos Tribunais. Desta feita, vale mencionar a decisão do Tribunal e Justiça de Pernambuco:

PENAL E PROCESSO PENAL. APELAÇÃO CRIMINAL. JÚRI. HOMICÍDIO QUALIFICADO. LEGÍTIMA DEFESA DA HONRA. ABSOLVIÇÃO. RECURSO DO MINISTÉRIO PÚBLICO. ALEGAÇÃO DE JULGAMENTO MANIFESTAMENTE CONTRÁRIO À PROVA DOS AUTOS. ANULAÇÃO. IMPOSSIBILIDADE. EXISTÊNCIA DE DUAS VERSÕES. OPÇÃO DOS JURADOS POR UMA DA TESES SUBSIDIADA EM ELEMENTOS PROBATÓRIOS CONTIDOS NOS AUTOS. RECURSO IMPROVIDO. 1. Anula-se o julgamento proferido pelo Tribunal do Júri, com fundamento no art. 593, inciso III, alínea d, nas hipóteses em que a decisão do Conselho de Sentença é arbitrária, dissociando-se completamente da prova dos autos. Existindo nos autos duas versões, não é manifestamente contrária à prova dos autos a decisão do Tribunal do Júri que acolhe, com base no conjunto probatório uma das 
teses ventiladas. Precedentes. 2.Recurso improvido. Decisão Unânime. (TJ-PE- ACR: 153844 PE 00000017, Relator: Antônio de Melo e Lima, Data de Julgamento: 17/12/2009, 3a Câmara Criminal, Data de Publicação: 02).

Em pleno século XXI, tal argumento sociológico sobrepõe-se ao direito à vida, sem proporcionalidade entre conduta da vítima e o crime praticado pelo autor, sendo acolhida a legítima defesa da honra em caso de adultério, que não é mais crime desde o advento da lei 11.106/2005. Assim observa Mirabete (2003, p. 69):

Sob influência do conceito bastante difundido de que quem não defende seu amor, sobre o qual tem genuínos direitos de propriedade, perde a honra e merece a reprovação social, tem-se decidido pela existência de legítima defesa da honra nos casos em que o marido mata a esposa adúltera, mas essa posição vem cedendo, mesmo nos tribunais populares, à orientação de que não há, no caso, a excludente da antijuridicidade.

Tal posicionamento tem permitido fôlego com as transformações sociais e passou a ser minoritário, com tendência a desaparecer com o advento da qualificadora e tende a desparecer quando ao feminicídio. Nesse sentido, faz-se necessário citar decisão do TJ/SC.

APELAÇÃO CRIMINAL. TRIBUNAL DO JÚRI. RÉU CONDENADO PELA PRÁTICA DE HOMICÍDIO DOLOSO QUALIFICADO PELO MOTIVO TORPE. CRIME COMETIDO NO ÂMBITO DAS RELAÇÕES DOMÉSTICAS. PLEITO DEFENSIVO DE ANULAÇÃO DA DECISÃO POR SER MANIFESTAMENTE CONTRÁRIA À PROVA DOS AUTOS. MATERIALIDADE E AUTORIA DEMONSTRADAS NO DECORRER DO PROCEDIMENTO ESCALONADO. RÉU CONFESSO. LEGÍTIMA DEFESA PRÓPRIA E DA HONRA REJEITADAS PELOS JURADOS MEDIANTE RESPOSTA NEGATIVA AO QUESITO GENÉRICO DE ABSOLVIÇÃO. SITUAÇÃO RETRATADA NOS AUTOS QUE NÃO SE AMOLDA AOS REQUISITOS DO ART. 25 DO CÓDIGO PENAL. ALEGAÇÃO DE QUE O DECISUM SE BASEOU EM DECLARAÇÕES PRESTADAS POR PESSOAS LIGADAS À VÍTIMA. LIVRE APRECIAÇÃO DAS PROVAS. JURADOS QUE OPTARAM 
POR UMA DAS VERSÕES DEDUZIDAS EM PLENÁRIO E QUE ESTÁ ESCORADA EM PROVAS SUBSTANCIOSAS. QUALIFICADORA DO MOTIVO TORPE. CIÚME QUE NÃO PODE SER DESCONSIDERADO PARA A CARACTERIZAÇÃO DA EXASPERADORA SE OS JURADOS ASSIM ENTENDERAM. CLÁUSULA DA SOBERANIA DOS VEREDICTOS QUE ABARCA TAL INTERPRETAÇÃO. APELANTE QUE DEMONSTRAVA POSSESSIVIDADE EXTREMA, PLENAMENTE DEMONSTRADA NO CONTEXTO PROBATÓRIO. EXASPERADORA MANTIDA. "Definir se o ciúme constitui ou não motivo torpe não guarda nenhuma relação com a questão probatória propriamente dita. Trata-se de tema que já resvala para o juízo de valoração subjetiva dos jurados, seara interditada à revisão da instância recursal em obséquio ao princípio constitucional da soberania dos veredictos [...]" (Des. Newton Janke). DOSIMETRIA- PENA FIXADA DE ACORDO COM OS PARÂMETROS LEGAIS- QUANTUM INALTERADO. RECURSO NÃO PROVIDO. (Ap. Crim. 2009.007898-3, Rel. Des. Moacyr de Moraes Lima Filho- j. 22.4.2009). JULGAMENTO ARBITRÁRIO NÃO CARACTERIZADO. INCIDÊNCIA DO DISPOSTO NO ART. 5, INC. XXXVIII, ALÍNEAS C E D, DA CONSTITUIÇÃO FEDERAL. RECURSO CONHECIDO E DESPROVIDO. (TJ-SC - APR: 20130599442 SC 2013.0599442 (Acórdão), Relator: Sérgio Rizelo, Data de Julgamento: 04/11/2013, Segunda Câmara Criminal Julgado).

No julgamento da apelação criminal pelo Tribunal de Justiça de Santa Catarina, o entendimento firmado pela Corte foi o de que não se admite a tese de legítima defesa da honra, no cometimento homicídio qualificado por motivo torpe. A decisão se fundamenta na falta de subsunção do contexto fático na previsão legal do art. 25, do Código Penal. Na hipótese, tratou-se de homicídio no âmbito da relação doméstica.

As estatísticas de homicídios passionais são alarmantes, em que assassinos lavam a honra com sangue e, muitas vezes, saem impunes, sendo absolvidos no tribunal do júri. Por muito tempo se admitia a ideia de que o cônjuge traído não só poderia como deveria lavar sua honra, tendo este a certeza da sua absolvição. 
Muito embora a sociedade tenha evoluído consideravelmente com relação a direitos iguais entre homens e mulheres, até pouco tempo atrás a honra tinha um foco diferenciado entre estes. Não havia igualdade, e a honra feminina se limitava tão somente ao seu comportamento íntimo, devendo sempre zelar pela sua dignidade, fidelidade para com seu companheiro e discrição, mantendo-se sempre submissa ao seu marido.

\section{CASOS HISTÓRICOS BRASILEIROS DE CRIMES PASSIONAIS}

Diversos casos envolvendo o homicídio passional foram registrados no Brasil. Dentre eles, um que merece destaque e que ganhou notoriedade à época do acontecido, ocorreu na década de 70 e ficou conhecido como Caso de Doca Street.

No ano de 1976, na Praia dos Ossos, litoral do Rio de Janeiro, o paulista Raul Fernandes do Amaral Street, conhecido por Doca Street assassinou sua companheira Ângela Diniz com três tiros no rosto e um na nuca simplesmente porque esta não queria dar continuidade ao relacionamento. Por conta da brutalidade e enorme comoção que houve, o movimento feminista protestou contra tamanha barbárie, iniciando campanhas para repudiar tal ato.

Essa época foi marcada por intensa manifestação da sociedade, onde até então havia total aceitação desse tipo de crime. Na época, o advogado Evandro Lins e Silva, alegou legitima defesa da honra, materializando que seu cliente agiu para lavar sua honra diante de um suposto caso de infidelidade, maximizando claramente o desprestígio que a mulher tinha. Vale lembrar que, muitas vezes, o que leva o homem ao cometimento do crime se dá pela não aceitação do término do relacionamento do que pela traição em si.

Em alguns casos, como neste, por exemplo, a defesa tenta, muitas vezes, macular a imagem da vítima, no intuito de procurar 
justificativas para o cometimento do crime, tentando retratá-la como indigna e a culpada por desencadear tamanha violência por parte do autor.

O desfecho desse caso ocorreu com a prisão de Doca, sendo este condenado a uma pena diminuta, com dois anos de reclusão com sursis (suspensão condicional da pena). Vale lembrar que, nesse tipo de condenação, o condenado não precisaria recolher-se à prisão, acarretando-Ihe praticamente sua absolvição. Na hipótese, seu advogado utilizou como tese a legítima defesa da honra, com excesso culposo, o que acabou em total e absoluto sucesso.

Pouco antes do julgamento, Doca concedeu entrevista à imprensa, declarando:

Essas são as piores horas de minha vida. Vejo de volta a tensão, o retomo dos fatos horríveis de 30 de dezembro de 1976 e tudo o que transformou minha mente em uma tela indescritivel, onde se vê um filme horrível. Sinto pena de meu pai, da mãe de Ângela, dos meus filhos, dos filhos dela. Mas, sobretudo, gostaria que o tempo voltasse e que a mulher que de fato amei entendesse toda a força do meu amor. Porque, no fundo, matei por amor. (Jornal da Tarde, 18/10/1979 apud ELUF, 2007).

Entretanto, por conta dos protestos realizados pelos movimentos feministas, a acusação recorreu, e Doca foi novamente levado a julgamento, dois anos depois, em novembro de 1981. Apesar de não suficiente, porém mais justo, Doca foi condenado, por homicídio qualificado, a quinze anos de reclusão, entendendo o júri, por cinco votos a dois, que ele não agiu em legítima defesa de direito algum, muito menos de sua honra ferida.

Por conta da sua ascensão na TV e no teatro à época, um caso de homicídio bastante conhecido e que chocou o Brasil pela tamanha brutalidade foi o da atriz Daniella Perez, que foi morta pelo então ator e colega Guilherme de Pádua. Era noite de dezembro de 1992, 
quando aos 22 anos de idade a atriz foi brutalmente assassinada com dezoito golpes de tesoura, por Guilherme e pela sua mulher, na época grávida, Paula Almeida Thomaz, de 19 anos, próximo a um matagal, na Barra da Tijuca, Rio de Janeiro.

Durante o processo criminal, a versão dos fatos foi alterada diversas vezes pelos assassinos, que a todo o momento entravam em contradição, se acusando mutuamente, imputando ao outro a autoria do crime.

Como em muitos outros casos, houve aqui uma tentativa de atribuir à vítima a culpa pelo crime. Guilherme declarou que era assediado de forma recorrente pela atriz, desencadeando crises de ciúmes em sua mulher Paula. Versão que não convenceu a muitos, já que a vítima era casada com o ator Raul Gazolla, pelo qual era aparentemente apaixonada.

A linha de raciocínio dos investigadores diante de afirmações de vários atores e colegas foi no sentido de que Guilherme nutria uma paixão doentia pela vítima, que não correspondia às suas investidas. Diante dessa negativa, planejou antecipadamente como executaria seu plano, absurdamente consentido pela sua mulher.

Os criminosos foram levados à júri popular por homicídio duplamente qualificado: motivo torpe e recurso que dificultou a defesa da vítima. Guilherme foi condenado a 19 anos de reclusão. Já Paula foi condenada a 18 anos e seis meses de reclusão, em razão da coautoria.

Por causa de um movimento liderado pela mãe da vítima, Glória Perez, houve a inclusão do homicídio qualificado no rol dos crimes hediondos, previstos na Lei n. 8.072/90. Desde então, as condutas criminosas altamente reprováveis passaram a ser tratadas com mais rigor, sendo agora o homicídio qualificado tratado de forma mais severa não havendo possibilidade de fiança, nem de cumprir a pena em regime aberto ou semiaberto. 
Um caso mais recente de homicídio passional e que também ficou bastante conhecido foi o do cirurgião plástico Farah Jorge Farah, que assassinou sua amante e ex-paciente. Era noite de 24 de janeiro de 2003, quando a dona-de-casa Maria do Carmo Alves, 46 anos, foi ao consultório do cirurgião plástico Farah Jorge Farah, na época com 53 anos, em Santana, zona norte de São Paulo. Foi justamente em seu ambiente de trabalho que o cirurgião assassinou sua amante, que teve seu corpo dividido em nove pedaços, acomodados em cinco sacos de lixo, depositados no porta-malas do carro de Farah, que declarou não se lembrar do que havia acontecido naquela noite. A perícia chegou à conclusão de que Maria pode ter sido esfaqueada no pescoço e posteriormente arrastada até a sala de cirurgia da clínica.

Ainda de acordo com a perícia, Farah voltou para casa, que ficava a poucos quarteirões, guardou o carro e depois de quatro horas retornou à clínica, onde permaneceu durante a madrugada, esquartejando a vítima. Valendo-se de seu conhecimento técnico e utilizando-se de instrumentos cirúrgicos, não teve grandes dificuldades em dissecar o corpo e retirar a pele de parte do rosto, do tórax e das pontas dos dedos das mãos e dos pés. Cuidadosamente, os pedaços do corpo foram acomodados numa banheira e cobertos com formol e água sanitária, evitando a decomposição, disfarçando o odor e ajudando a retirar o sangue dos membros e reduzir o peso da vítima, de 66 quilos para 30.

Dias depois, o médico se internou na clínica psiquiátrica Granja Julieta, na zona sul de São Paulo e, ao receber a visita da sobrinha, ele confessou o crime. A prisão preventiva do médico foi decretada pela Justiça a pedido da Promotoria, em 28 de janeiro, sendo ele levado no mesmo dia ao 13음 Distrito Policial para interrogatório. $\mathrm{Na}$ oportunidade, ele relatou que a vítima, inconformada com o fim do relacionamento, ligava constantemente fazendo ameaças e perseguindo-o. Alega ainda que, na noite do crime, logo após Maria 
chegar ao seu consultório, ele perdeu a consciência e recuperando os sentidos somente no domingo à tarde.

O médico-cirurgião permaneceu preso na carceragem do 130 Distrito Policial durante 4 anos e quatro meses, até que, em 29 de maio de 2007, a Segunda Turma do Supremo Tribunal Federal the concedeu um habeas corpus.

Levado a júri em 15 de abril de 2008, Farah respondeu pelos crimes de homicídio duplamente qualificado - por motivo torpe e emprego de meio que impossibilitou a defesa da vítima - e ocultação de cadáver. Os advogados do médico entenderam que Farah deveria ser considerado semi-imputável - capaz de entender o crime, mas sem condições de se controlar - e defenderam a tese de homicídio privilegiado, sob alegação de que ele era perseguido por Maria do Carmo.

Com duração de três dias, o julgamento de Farah teve como resultado sua condenação à pena mínima nos dois crimes: 12 anos de prisão pelo homicídio, mais um ano e multa de meio salário mínimo por ocultação de cadáver. Entretanto, por entendimento da 2 a Câmara de Direito Criminal do Tribunal de Justiça de São Paulo, foi pedida a anulação do julgamento, acolhendo o argumento da defesa de que o conselho de sentença havia ignorado o laudo oficial sobre Farah, segundo o qual o réu estaria semi-imputável no momento do crime. Aos 64 anos, o ex-médico foi levado ao banco dos réus em 12 de abril de 2014, no Fórum Criminal da Barra Funda. No total, 16 testemunhas foram ouvidas, sendo oito de acusação e oito de defesa, além do próprio Farah, que manteve a alegação de legítima defesa e que era perseguido pela vítima. Nesse novo julgamento, O ex-médico foi condenado a 16 anos de prisão por homicídio e esquartejamento.

Nesses três casos, ocorridos num lapso temporal distinto, a figura da legítima defesa foi utilizada na tentativa de justificar a conduta dos agressores, impondo às vítimas a culpa pelos atos por eles praticados. Muitos outros casos de homicídio passional lamentavelmente 
estão elencados em dados da polícia, lembrando também que alguns não estampam os dados estatísticos por diversos motivos.

\section{CONSIDERAÇÕES FINAIS}

Muito embora o homicídio passional seja considerado pela sociedade como um crime que causa grande repúdio pela sua torpeza, é necessário evidenciar o perfil do criminoso passional, o que é bem difícil de definir, uma vez que fatores internos e externos estão diretamente ligados para sua concretização. No presente trabalho, foi possível identificar as teses defensivas desses crimes, bem como as alegações que o homicida passional utiliza para justificar o cometimento de tal conduta, mostrando as espécies da excludente de ilicitude aceita em nosso ordenamento jurídico, de modo que tal excludente não pode ser aplicada nas hipóteses de cometimento de homicídio na defesa da honra. Restou comprovado que atualmente a tese da legítima defesa não é mais aceita no seio da nossa sociedade, de forma que, mesmo com o assustador número de vítimas desse tipo de crime, hoje se tem mais rigor na punição para tal ato abominável. Dessa forma, mostrou-se neste trabalho que a definição de homicídio passional é encontrada na doutrina, sendo atribuída aos doutrinadores o seu conceito, cabendo ao Código Penal tão somente tratar de uma espécie do homicídio simples. Assim, a legítima defesa da honra se trata de um privilégio para o crime de homicídio, em que o ofensor não fica mais impune em relação ao crime que cometeu, tendo, porém em seu favor a diminuição de pena relacionada ao privilégio.

\section{REFERÊNCIAS}

BERALDO JÚNIOR, Benedito Raymundo. Legítima defesa da honra como causa excludente de antijuridicidade. Jus Navigandi, Terezina, ano 8, n. 367, 9 jul. 2004. Disponível em: <http://www1.jus.com.br/doutrina/texto. asp?id=5418>. Acesso em: 12 fev. 2016. 
BERNARDES, Marcelo de Rezende. A realidade vigente dos chamados crimes passionais. Correio Forense, 12 set. 2007. Acesso em: 13 fev. 2016.

BITENCOURT, Cezar Roberto. Código Penal Comentado. 5. ed. São Paulo: Saraiva, 2009.

BRASIL. Código Penal. Decreto-Lei no 2.848, de 7 de dezembro de 1940. Vade mecum. São Paulo: Saraiva, 2013.

BRASIL. Constituição (1988). Constituição da República Federativa do Brasil. Brasília, DF: Senado, 1998.

CAPEZ, Fernando. Curso de direito penal. 7. ed. São Paulo: Saraiva, 2007. v. 2, parte especial.

DELMANTO, Celso et al. Código penal comentado. 7. ed. Rio de Janeiro: Renovar, 2008.

ELUF, Luiza Nagib. A paixão no banco dos réus: casos passionais célebres de Pontes Visgueiro a Pimenta Neves. 3. ed. São Paulo: Saraiva, 2007.

FERLIN, Danielly. Os crimes passionais à luz da legislação brasileira. JUS, jun. 2014. Disponível em: <https://jus.com.br/artigos/29111/os-crimespassionais-a-luz-da-legislacao-brasileira>. Acesso em: 13 fev. 2016.

MICHAELIS: moderno dicionário da língua portuguesa. São Paulo: Companhia Melhoramentos, 1998. (Dicionários Michaelis).

MIRABETE, Julio Fabbrini. Manual de Direito Penal. Parte especial. Arts. 121 a 234 do CP. São Paulo: Atlas, 2003. v. 2.

NUCCl, Guilherme de Souza. Manual de direito penal: parte geral. Parte especial. 8. ed. ren., atual e ampl. São Paulo: Ed. Tribunais, 2012.

PERNAMBUCO. Tribunal de Justiça do Estado de Pernambuco. Apelação Criminal no 153844 PE. Disponível em: <http://tj-pe.jusbrasil.com.br/ jurisprudencia/15479050/apelacao-criminal-acr-153844-pe-00000017>. Acesso em: 4 abr. 2016.

SANTANA, Olivia. E que a voz da igualdade seja sempre a voz! Correio*, mar. 2015. Disponível em: <http://www.correio24horas.com.br/detalhe/noticia/ olivia-santana-e-que-a-voz-da-igualdade-seja-sempre-a-nossa-voz/?cHash= 09c9aad762fd9c5c61ca69c644901785>. Acesso em: 23 fev. 2016. 
TOIGO, Daliane Mayellen. Breve análise das teses defensivas da legítima defesa da honra e da privilegiadora da violenta emoção no tribunal do júri em homicídios passionais praticados por homens contra mulheres. Unoesc \& Ciência - ACSA, Joaçaba, v. 1, n. 1, p. 13-20, jan./jun. 2010. Disponível em: <http://editora.unoesc.edu.br/index.php/acsa/article/view/66/34>. Acesso em: 7 abr. 2016. 